\title{
Environmental Disclosure in Spain: Corporate Characteristics and Media Exposure
}

\section{Manuel García-Ayuso \& Carlos Larrinaga}

To cite this article: Manuel García-Ayuso \& Carlos Larrinaga (2003) Environmental Disclosure in Spain: Corporate Characteristics and Media Exposure, Spanish Journal of Finance and Accounting / Revista Española de Financiación y Contabilidad, 32:115, 184-214, DOI: 10.1080/02102412.2003.10779479

To link to this article: https://doi.org/10.1080/02102412.2003.10779479

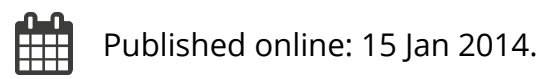

Submit your article to this journal ๔

Џll Article views: 118

Citing articles: 16 View citing articles $\square]$ 


\title{
ENVIRONMENTAL DISCLOSURE IN SPAIN: CORPORATE CHARACTERISTICS AND MEDIA EXPOSURE.
}

\author{
By \\ Manuel García-Ayuso \\ Universidad de Sevilla \\ Carlos Larrinaga \\ Universidad de Burgos
}

Fourth draft: February 17, 2003.

Address correspondence to:

Manuel García-Ayuso

Departamento de Contabilidad

Universidad de Sevilla

Avenida Ramón y Cajal, 1

41018 Sevilla

SPAIN

E-mail: mgayuso@us.es

Manuel Garcia-Ayuso is Carlos Cubillo professor Accounting and Auditing at the Department of Accounting of the University of Sevilla. Carlos Larrinaga is associate professor in accounting at the Department of Business Administration of the University of Burgos. Financial support of the DGICYT of the Spanish Ministry of Education (Projects SEC2001-2633 and PB98-0415) is gratefully acknowledged. Manuel García-Ayuso also thanks the funding provided by the Spanish Association of Accounting and Business Administration to the 
Carlos Cubillo Chair in Accounting and Auditing. We are indebted to Carmen Pineda for making her databases available for this study. The authors appreciate comments from two anonymous reviewers.

\begin{abstract}
Social and environmental issues have become a major concern for accounting research over the past two decades. Social and Environmental Accounting has attracted the attention of a number of researchers attempting to understand, explain and predict the disclosure of information on the social and environmental implications of business activities. Empirical research has hypothesized that size, profitability and the potential environmental impact of the firm are the main factors explaining the amount of information disclosed. On the other hand, several studies have focused on the motivations for disclosing environmental information, hypothesizing that disclosures are aimed at building or sustaining corporate legitimacy.

$W_{e}$ test the main hypotheses developed to date by empirical research with regard to the disclosure of environmental information based on a sample of companies listed on the Madrid Stock Exchange. Results of a content analysis show that firms disclosing environmental information tend to be larger, have higher risk (measured by the beta coefficient) and operate in industries that have a high potential environmental impact. The environmental implications of the activities carried out by these companies also seem to receive more attention from print media. Our results also provide evidence that two factors directly associated with the amount of environmental information disclosed are the potential environmental impact of the industry and the extent of media coverage of the firms.
\end{abstract}

\title{
KEYWORDS
}

Environmental Disclosures, Corporate Characteristics, Content Analysis, Media Coverage, Spain.

\section{DATA AVAILABILITY}

Data used in this study was collected from publicly available sources and may be obtained from the authors upon request 


\section{INTRODUCTION}

The amount and the quality of environmental information disclosed by business companies has increased remarkably over the last few decades. Surveys have documented an increase in environmental disclosures in the late eighties and nineties in Australia (Deegan and Gordon, 1996), Spain (Archel, 2001; Moneva and Llena, 2000), the United Kingdom (Gray et al., 1995a) and elsewhere. According to an international survey conducted by KPMG (2002), $49 \%$ of the top 100 companies in 19 countries disclose social and environmental information as part of their annual reports, with $23 \%$ of them publishing a separate social and environmental report.

Furthermore, there is increasing evidence on the usefulness of environmental information for the analysis of the financial position of companies as well as for other purposes (e.g. their inclusion in ethical funds or in sustainability indexes).The study carried out by Deegan and Rankin (1997) revealed that environmental disclosure is relevant for a wide variety of users of the financial reports, such as shareholders, individuals within the company and review organizations. Their results also indicate that potential users consider that the annual report is more important than any other source of information in order to understand the environmental performance of the corporation.

The relevance of environmental accounting has also been recognized by standard setting bodies. Today, several European countries require companies to disclose environmental information as part of their financial reports. In Spain, an accounting standard issued in 1998 requires business companies to disclose details about their environmental expenses, assets and liabilities in the notes to the financial statements (Larrinaga et al., 2002).

The increase of social and environmental accounting has attracted the attention of research which has attempted to codify and explain an area of corporate activity which lies outside the domain of conventional accounting (Gray et al., 2001). A major concern for social and environmental accounting research has been the analysis of the relationship between corporate characteristics and the extent and quality of the information disclosed by firms. 
Empirical studies have hypothesized that large and profitable firms, as well as those listed in industries that have a greater potential impact on the environment (sensitive industries) ${ }^{1}$, tend to disclose more social and environmental information (see Gray et al., 2001 for a review). Another stream of research has focused on managerial incentives for disclosing environmental information. Particularly interesting are the research studies conducted within the framework of the so-called Legitimacy Theory (hereafter LT), according to which environmental information is disclosed in order to build or sustain corporate legitimacy, i.e. the societal acceptability of corporate actions (see Deegan, 2002 for a review). A good example of this approach towards the analysis of environmental disclosure is the study by Deegan and Rankin (1996) documenting that Australian companies only revealed information that was favorable to their corporate image and that the amount of positive information was even larger in the case of companies that had been successfully prosecuted for environmental offences.

This paper tests in the Spanish context the hypotheses developed and tested in other countries by previous empirical studies. We first analyze the relationship between several corporate characteristics and the amount of environmental information disclosed by business companies and, then assess the extent to which environmental disclosures are driven by managers' desire to gain or enhance corporate legitimacy.

The remainder of the paper is organized as follows. The next section reviews previous empirical studies on environmental disclosures and develops the hypotheses tested. Section three describes the method and data analyzed and section four presents a discussion of our results. The fifth section contains a summary and some concluding comments.

\footnotetext{
${ }^{1}$ Deegan and Rankin (1997, p. 81) define environmental sensitivity based on "a questionnaire administered to environmental lobby groups in which office bearers were required to rate industries (on a 05 scale) on the basis of whether the industry had been made the focus of action as a result of its environmental activities" 


\section{PREVIOUS RESEARCH}

\section{Empirical evidence on environmental disclosure in Spain}

Because environmental accounting has not been a major issue in the agenda of Spanish researchers, the empirical evidence available in this area is scarce. However, there seems to be now a growing number of studies focusing on environmental disclosures. An early study was carried out by Carmona and Carrasco (1988). They analyzed social and environmental information disclosed by 61 Spanish firms in their 1985 annual report and found that the profitability was not consistently related to the amount of social and environmental information disclosed.

More recently, Moneva and Llena (1996) analyzed social and environmental disclosures made in 1992 by 47 industrial companies. They reported that 33 firms (70\%) disclosed some information on environmental issues, but only 6 firms (13\%) included some reference in the notes to the financial statements. Not surprisingly, a greater amount of environmental information was found in the annual reports of electric utilities, and the firms in the pulp and paper and chemical industries. In general, social and environmental information was simply a description of their environmental activities. No relationship appeared to exist between the decision to disclose social and environmental information nor was there different measures of profitability or the existence of a specific market regulation. In a further survey, Moneva and Llena (2000) analyzed the environmental disclosure practices of 70 companies in 1992, 1993 and 1994. The information disclosed was found to be rather general, lacking details, included among the voluntary information in the annual reports and concentrated in regulated industries. They also reported a consistent increase in both, the number of disclosing companies and the extent of environmental disclosure. Finally, Archel and Lizarraga (2001) surveyed environmental disclosures in the 1995 to 1998 annual reports of a sample of Spanish companies. They consistently found that both, size and environmental sensitiveness are corporate characteristics that explain the extent of environmental information. 
This paper extends this research by providing an analysis of the relationship between the disclosure of environmental information and several corporate characteristics, industry factors and the level of external scrutiny of the firm's activities.

\section{Determinants and motivations of environmental disclosures}

In order to justify our empirical tests, we next discuss the nature and potential impact of the main factors driving the disclosure of environmental information by business companies.

Size

There is consistent evidence on the relationship between different measures of size and environmental disclosures (see Gray et al., 2001 for an international review and Archel and Lizarraga, 2001, for Spain). This evidence has received different interpretations depending on the theoretical framework adopted by the researcher (Hackston and Milne, 1996; Gray et al., 2001). However, it could be argued that larger firms are subject to stronger pressure from stakeholders and, consequently, they are expected to find more persuasive arguments (depending on the theory) to disclose environmental information. Accordingly, we test whether there is a positive relationship between the amount of environmental information disclosed and the size of the firm.

\section{Risk}

Financial accounting information provides investors with useful information that helps them reduce the possible errors when attempting to identify the best value creation opportunities. Reducing the risk of economic losses will likely reduce the cost of capital (Bushman and Smith, 2001). There is in the accounting literature a general agreement on the idea that by disclosing more information a company is able to lower its cost of capital at the possible expense of incurring losses due to the disclosure of proprietary information (Dye 2001, p. 224). More specifically, Verrechia (2001, p. 166), states that the disclosure of financial information by managers reduces the information asymmetry component of the cost of capital, that is, the factor by which investors discount firm equity offerings in anticipation of transaction costs that may arise from adverse selections in the event that they liquidate 
their equity holdings at some future date. Li, Richardson and Thornton (1997) have provided empirical evidence supporting the hypothesis that firms are more likely to disclose environmental information when the risk of incurring proprietary costs decreases. In summary, based on the conclusions of previous theoretical and empirical studies on voluntary disclosure, firms with higher levels of risk are expected to disclose a greater amount of voluntary financial information.

During the period analyzed in our study, Spanish accounting standards did not require the disclosure of information on environmental issues, with the exception of the allowances arising as a result of probable future environmental liabilities. The disclosure of voluntary information on environmental issues during that period suggests that the managers of Spanish firms were willing to reduce information asymmetries providing investors with the data they consider relevant regarding the environmental performance of the firm. In order to test for the existence of an association between risk and the disclosure of environmental information by Spanish companies we analyzed the extent to which the market model beta is associated with the decision to disclose and the amount of information disclosed. Trotman and Bradley (1981) correctly point out that it is far from clear whether systematic risk would be lower for firms that show environmental responsibility (i.e., disclose environmental information) or higher, in the understanding that managers could see environmental disclosure as a means of reducing risk. Therefore, we make no a priori prediction on the sign of the relationship between betas and the extent of environmental disclosure.

\section{Profitability}

Although Hackston and Milne (1996) suggest that that profitability allows management enough flexibility to detract funds from shareholders to undertake social and environmental programs and, therefore, there could be a direct relationship between corporate profitability and the relevance attached by the firm to environmental issues, published empirical studies have not documented the existence of a consistent relationship between profitability and the level of environmental disclosures (see Gray et al., 2001 for an international review and Carmona and Carrasco, 1988 and Moneva and Llena, 1996 for Spain). Gray et al. (2001) found a significant but weak association between profitability and 
environmental disclosure in the U.K. In an attempt to provide further evidence on this issue within the Spanish context, we test whether the level of environmental disclosure is associated with corporate profitability without making any a priori prediction on the sign of such a relationship.

\section{Environmental sensitivity}

It has been argued that the more attention one industry receives from stakeholders, the greater the incentives for companies in that industry to make environmental disclosures (Deegan and Gordon, 1996; Bewley and Li, 2000). In that regard, environmental sensitivity is primarily driven by the potential (or actual) impact that the firms operating in a given industry may have (or have had) on the environment. ${ }^{2}$ With some exceptions (Alnajjar, 2000), empirical research has found that firms operating in more sensitive industries tend to disclose a greater amount of social and environmental information (Patten, 1991; Roberts, 1992; Walden and Schwartz, 1997; Bewley and Li, 2000; and Archel and Lizarraga, 2001). Therefore, we test whether the level of environmental disclosure is higher in the case of Spanish firms operating in sensitive industries.

Deegan and Gordon (1996) assessed the environmental sensitiveness of different industries by means of a survey among environmental lobbying groups. According to the responses received, the top ten sensitive industries were: uranium mining, chemicals, coal, transport, oil/gas exploration, plastics manufacturing, oil/gas production, gas distribution, and paper and timber manufacturing. These results are consistent with the classifications used in other studies (Patten, 1991; Roberts, 1992; Hackston and Milne, 1996), except that none of the later studies include the transportation industry. In view of the companies included in our sample we identified four sensitive industries: oil and mining, electricity and gas, chemical and pulp and paper.

\section{Media exposure}

\footnotetext{
2 One could argue that the potential to have a negative impact on the environment is a firm-specific characteristic, as companies within the same industry may carry out different activities, be settled in distant locations and have designed and implemented alternative production procedures. However, given the
} 


\section{ENVIRONMENTAL DISCLOSURE IN SPAIN: CORPORATE CHARACTERISTICS AND MEDIA EXPOSURE}

Several studies have shown that the extent of environmental disclosure is not associated with the environmental performance of the firm (Ingram and Frazier, 1980; Wiseman, 1982; Rockness, 1985 and Deegan and Rankin, 1996), but rather with the external pressure exerted by society in general and, specifically, by lobbying groups. Li, Richardson and Thornton (1997) document that firms are more likely to disclose environmental information as propensity increases and as outsiders' knowledge of their environmental liabilities increases.

Provided that companies disclose environmental information as a result of external pressures, the extent and quality of the information published is likely to be significantly influenced by management's interests. The results of some recent studies appear to be consistent with this view, as they indicate that the disclosure of environmental information is self-laudatory, selective and intended to improve the firm's relationships with its stakeholders (Harte and Owen, 1992; Deegan and Rankin, 1996).

The motivations of management have been studied within the framework of the Legitimacy and (Deegan, 2002) as well as by a number of studies of the Voluntary Disclosure of Financial Information (Bewley and Li, 2000) theories. According to the LT, a company's performance is legitimate when it is judged to be fair and worthy of support, that is, when it is socially accepted. Legitimacy gaps arise when societal expectations of the firm's behavior differ form societal perceptions of its behavior. In these circumstances society could revoke the organization's 'contract' to continue its operations. Therefore, legitimacy has been seen as a resource on which the organization is dependent for survival. Deegan (2002) contends that LT overlaps with a number of theories, but this discussion is beyond the scope of this paper.

The relevant issue here is that, because LT is based on perceptions, it predicts that information will be used to gain, recover, maintain and enhance corporate legitimacy. For an environmental action to be effective it needs publicity. Thus, disclosure of environmental information could be seen as a method by means of which managers may attempt to influence

homogeneity of the four sensitive industries analyzed in our study it appears reasonable to consider that the potential negative impact on the environment may be an industry-specific factor. 
public expectations and perceptions, so as to seek congruence between their own values and actions and those considered by society as appropriate (Guthrie and Parker, 1989; Patten, 1992; Deegan and Rankin, 1996). For example, Patten (1992) found that petroleum companies significantly increased their environmental disclosures subsequent to the Alaskan Exxon Valdez oil spill. However, some empirical studies have not found support for LT either, in time-series (Guthrie and Parker, 1989) or in cross-sectional studies (Hughes et al., 2001).

Accordingly, within the framework of LT, the amount and the quality of environmental information disclosed are expected to change as a result of the degree of public scrutiny of the firm. Brown and Deegan (1998) provided a theoretical link between LT and the Media Agenda Setting Theory with regard to environmental disclosure. They argued that increased media attention is likely to increase public concern for an issue. Thus, one could argue that the press media can influence public perceptions and generate (or at least be indicative of) a legitimacy gap. Brown and Deegan (1998) partially confirmed that the level of environmental disclosure was not only associated with the level of print media coverage given to the environmental implications of the industries but also to the level of negative print media coverage of their environmental impacts. The results obtained by Bewley and Li (2000) were similar. However, instead of considering the media coverage within industries, as in Brown and Deegan (1998), the media coverage of the environmental implications of particular firms could be considered a signal for its particular legitimacy gap and, arguably, be more related with managers' decision to disclose environmental information. This is consistent with the approach followed by Bewley and Li (2000). Thus, based on the argument of Brown and Deegan (1998) we test whether the higher (lower) the level of print media coverage of the environmental implications of a firm's activities, the higher (lower) is the amount of environmental information disclosed by managers. We also assess the extent to which the greater (lower) the amount of bad news published by the press media regarding the environmental impact of a firm, the greater (lower) is the amount of environmental information published by the firm.

\section{DESCRIPTION OF THE STUDY}


The First Earth Summit in Rio, in 1992, marked a milestone in the steady growth of environmental consciousness. All over the world, firms started to disclose environmental information in the late eighties. This is also true in Spain, where firms have steadily increased the amount of voluntary environmental disclosure in the nineties (Moneva and Llena, 2000; Archel and Lizarraga, 2001). Therefore, analyzing the disclosure of environmental information in the period 1991-1995, around the First Earth Summit, could provide relevant insights into the determinants and motivations of voluntary environmental disclosures.

\section{Sample}

The study is based on a sample of industrial firms listed on the Madrid Stock Exchange between 1991 and 1995. Our initial sample included all the 124 non-financial companies continuously traded during that period. However, 11 companies were excluded because their financial statements for the year 1995 were not available. A further company was excluded as in most years its annual report was not comparable with the rest of the companies in the sample. Therefore, our final sample comprises 112 firms with a total number of 560 firm-year observations, out of which 142 annual reports were found to include environmental information.

Annual reports, daily stock prices as well as information on dividends, new issues and splits were obtained from the records of the Spanish Securities and Exchange Commission (CNMV). Our sample has the advantage of consisting of the lions share of non-financial companies listed on the Spanish stock market. However, it must be borne in mind that the stocks of a large number of medium and large size Spanish companies are not traded in the stock market and, consequently, are not considered in our study. However, we believe our results are representative, as Moneva and Llena (2000) have demonstrated that there are no significant differences in environmental disclosure policies between large quoted companies and the large unquoted companies.

\section{Variables}


ENVIRONMENTAL DISCLOSURE IN SPAIN:

CORPORATE CHARACTERISTICS AND MEDIA

EXPOSURE

\section{Level of environmental disclosure}

In order to develop some measure of environmental disclosure, we carried out a thorough content analysis of the annual reports filled out between 1991 and 1995 by all the companies in our sample. It involved a revision of the balance sheet, the income statement, the notes to the annual accounts, the audit report and the management report.

Gray et al. (1995b) contend that defining what is environmental disclosure is an arbitrary exercise. However, we followed the definitions made by Gray et al. (1995b) and Deegan and Rankin (1996). Thus, we excluded environmental disclosures when they were part of the business (Gray et al., 1995b). Some examples of environmental disclosures considered are any statement and information related with: environmental policies, plans (mainly environmental management schemes) and declarations; investments in pollution abatement devices and processes; pollution remediation; recycling activities; recognition of the firm's polluting effects; and pollution fines and any other environmental cost, investment or benefit.

In our analysis, we tried to distinguish between positive and negative disclosures. However, consistent with prior evidence (Deegan and Gordon, 1996) we only found a few cases that included bad news related to the financial effect of past pollution.

In content analysis, several alternatives have been proposed in order to measure the amount of environmental reporting (Unerman, 1999). Some studies (Archel and Lizarraga, 2001) have used classification schemes to provide a number of disclosures (i.e., the themes expressed in the analyzed text). However, Gray et al. (1995b) suggest that the amount of disclosures (number of words, sentences or pages) provides richer data and automatically encompasses the number of disclosures. Proponents of the number of words, such as Deegan and Gordon (1996), have argued that this method can record the level of disclosure in greater detail. Advocates of the number of sentences (Hackston and Milne, 1996; Milne and Adler, 1999) argue that these units, rather than words, convey meaning. It seems now widely accepted (Gray et al., 1995b; Hackston and Milne, 1996; Unerman, 1999) that the number of pages is the preferred method for computing the amount of disclosure. Because it reflects the 
total space given to environmental issues, the importance attached to that theme can be inferred. Unerman (1999) also contend that the number of pages can capture non-narrative elements of disclosure, mainly photographs.

Therefore, considering the arguments in favor of the number of pages, we designed two measures of the level of environmental disclosure. First, in order to measure the absolute amount of environmental information disclosed, we computed the total number of lines in the annual report that included environmental disclosures, including, if appropriate, the equivalent number of lines to photographs (LINE). Then, we computed the total number of lines in the annual report considering the number of pages and the standard number of lines per page. Finally, dividing LINE by the total number of lines in the annual report we derived the second variable (SPACE) that provides an idea of the space given to environmental issues out of the total space in the annual report and, therefore, provides an indication of the importance attached to environmental issues in the annual report (Gray et al., 1995b). Even though our measures of environmental disclosure are not exactly the same used by (Gray et al., 1995b), we believe our results are consistent and may be comparable with those of previous studies as it is unlikely that measurement errors appear as a result of the technique chosen (Hackston and Milne, 1996).

The LINE variable is expressed in units (number of lines), whereas the SPACE variable is expressed in per-thousand units, that is, number of lines of environmental disclosures in each thousand lines in the annual report. These two variables allow us to analyze the general trend in the disclosure of environmental information by Spanish listed companies. However, since their values may be affected by extreme observations due to the large or small amount of environmental information disclosed occasionally by companies that do not have a stable environmental disclosure policy, we decided to restrict our analysis to the sub-sample of companies disclosing environmental information in all years to obtain further insight on the possible changes in voluntary disclosure policies among companies actually committed to the disclosure of environmental information. For that purpose we derived two variables from LINE and SPACE: LINEFREQ is the total number of lines of environmental information in the annual reports of the 12 firms that made environmental disclosures in every 


\section{ENVIRONMENTAL DISCLOSURE IN SPAIN: CORPORATE CHARACTERISTICS AND MEDIA EXPOSURE}

annual report in the five years considered in our study. SPACEFREQ is the number of lines of environmental information relative to the total number of lines in the annual reports of the firms that disclosed environmental information in all years. A further variable, SPO, reflects for each year the number of disclosing companies that did not make environmental disclosures in all the remaining years.

Subsequently, a research instrument was designed to record environmental disclosures. Once the main criteria for the analysis were established, the sample was divided and each author carried out a content analysis of $50 \%$ of the annual reports. In order to limit inconsistencies in the interpretation of the environmental disclosure categories and in the application of the research instrument, a sub-set of annual reports was randomly chosen and analyzed jointly.

The annual reports were obtained from a database published by the CNMV. Spanish listed companies must submit their annual accounts (balance sheet, income statement and notes to the financial statements), the audit report and the management report to the CNMV within the six months following the balance sheet date. Thus, in our analysis we did not consider any voluntary information beyond that included in the management report. However, listed companies usually prepare a brochure that is later disclosed among their shareholders at the time of the general meeting and may contain a greater amount of voluntary information than the documents filed in the CNMV. We carried out a comparative analysis of the environmental information disclosed by a random subsample of firms in the reports filed in the CNMV and in the annual brochures prepared for the shareholders general meeting. ${ }^{3}$ The subset examined included 116 annual reports (21\% of the 560 firm-year observations covered in our sample). We computed the LINE variable and the SPACE variable for both version of the annual report. Descriptive statistics are displayed in TABLE 1 (panel A).

\footnotetext{
${ }^{3}$ We thank the Carlos III University for granting us access to its Library, where these brochures were filed. The randomly chosen subset of our sample was defined as follows: one company of the total sample (CNMV reports) was selected and we searched its parallel annual brochures in the library. When the annual brochure was found, we computed the environmental disclosure measures (LINE and SPACE) and this annual report was included in the subset of the sample. This process was repeated in alphabetic order for approximately half of the total sample.
} 


\section{ENVIRONMENTAL DISCLOSURE IN SPAIN: CORPORATE CHARACTERISTICS AND MEDIA EXPOSURE}

Spearman rank-order correlation coefficients ${ }^{4}$ were computed for the LINE and SPACE variables obtained from the reports filed in the CNMV (line1 and space1) and from the brochures prepared for the shareholders' general meeting (line2 and space2). The absolute amount of environmental disclosure (LINE) is greater in the brochures distributed by firms among their shareholders. However, the values of the SPACE variable are similar in the reports filed in the CNMV and the brochures delivered at the shareholders' meeting. This indicates that the amount of environmental information included in the annual reports filed in the records of the CNMV is consistent with the amount disclosed in the brochures subsequently distributed by listed firms among their shareholders. This is confirmed by the statistics in panel B of TABLE 1. The amount of environmental information included by Spanish listed companies in the reports filed in the CNMV and in the brochures they disclose in their general meetings are highly and significantly correlated. Therefore, the financial reports available in the records of the CNMV provide a reliable basis for the analysis of the environmental disclosure policies of Spanish listed companies.

\section{TABLE 1}

Comparative analysis of environmental disclosure in a randomly chosen subset ${ }^{\mathrm{a}}$ of the sample CNMV reports and their parallel annual brochures (1991-1995) ${ }^{\text {b }}$

PANEL A: Descriptive Statistics

\begin{tabular}{|lllll|}
\hline N=116 & line1 & line2 & space1 & space2 \\
Mean & 7.89 & 12.81 & 2.88 & 2.22 \\
Std. Dev. & 17.72 & 27.86 & 6.43 & 4.17 \\
Max. & 82.00 & 151.00 & 40.71 & 21.51 \\
Min. & 0.00 & 0.00 & 0.00 & 0.00 \\
\hline
\end{tabular}

PANEL B: Spearman rank-order correlation coefficients between environmental disclosure in CNMV annual reports and annual brochures

\begin{tabular}{|lll|}
\hline line2 & $\begin{array}{l}\text { line1 } \\
\text { space2 }\end{array}$ & space1 \\
\hline
\end{tabular}

a see footnote 3

b line1 is the total number of lines of environmental information, for the annual reports submitted by firms to the CNMV.

\footnotetext{
${ }^{4}$ We decided to compute Spearman rank correlation coefficients as the variables analyzed were not found to be normally distributed.
} 
line 2 is the total number of lines of environmental information, for the annual reports published by firms.

space1 is the number of lines of environmental information relative (per thousand) to the total information disclosed in the annual report, for the annual reports submitted by firms to the CNMV.

space 2 is the number of lines of environmental information relative (per thousand) to the total information disclosed in the annual report, for the annual reports published by firms.

*** Signific ant at the $99 \%$ level.

\section{Profitability and other corporate characteristics}

Profitability was measured in accounting terms computing both, the Return on Assets (ROA) and the Return on Equity (ROE) ratios. The measure of earnings used $\left(\mathrm{X}_{\mathrm{it}}\right)$ was earnings before extraordinary items and discontinuing operations. The book value of equity and the total asset figures were used in our calculations as shown in the balance sheet. We computed annual stock returns as the average monthly return observed during the twelve months following the third month after year-end. Market betas $\left(\hat{a}_{i t}\right)$ were estimated using a minimum of 36 consecutive stock returns and a maximum of 60 prior to the balance sheet date.

Size and leverage are two corporate characteristics frequently considered as explanatory variables in empirical studies of accounting disclosure. We measured size as the logarithm of the total market capitalization of the firm. The measure of leverage used in our analysis was the total debt to equity ratio. Moreover, we used two other measures that have been thoroughly analyzed by recent research because of their relevance for investment decision making. The Earnings-to-Price and the Book-to-Market ratios were computed using stock prices at the end of the third month after year-end. Finally, firm size $\left(S_{i t}\right)$ was measured as the logarithm of the total market capitalization of the firm three months after the balance sheet date.

\section{Environmental sensitivity}

According to the discussion in section three, the environmental sensitivity variable $\left(D_{i t}\right)$ is assumed to be consistently associated with the pressure that society exerts the company because of the environmental visibility of the industry in which it operates. For the purposes of this study, environmental sensitivity is proxied by using a dummy variable that 
takes on the value 1 for firms in the oil and mining, electricity and gas, chemical and pulp and paper industries and 0 for all other industries.

\section{Media exposure}

In order to develop a measure of the media coverage of the environmental impact of a given firm, we counted in each year the number of articles in the main Spanish newspapers and magazines containing any reference to the relationship between the company and environmental issues.

Articles were obtained from the records of the BARATZ database, which includes all articles on economic, social and political issues published by 33 Spanish periodicals and journals since 1981. A search was carried out for each corporation, using as keywords the name of the company and environment (in Spanish medio ambiente). It is very unlikely that a Spanish article dealing with environmental issues will not include this word. Subsequently, the search results were carefully examined to exclude articles that did not specifically relate each company with environmental issues. The Media Articles variable is measured as the number of articles published in a given year dealing with the relationship between a firm and the environment.

To make our results comparable with those of Brown and Deegan (1998), we selected negative articles, i.e. those providing the view that the activities carried out by the company have a negative impact on the environment. Therefore, the Negative Media Articles variable is measured as the number of articles that, for a given year, provide an unfavorable view of the corporate activities in relation to the environment.

Finally, in order to evaluate the general evolution of the concern for environmental issues in Spain, we also considered the total number of articles dealing with the environment Total Environmental Articles for each year. Thus, we computed the ratio of the total number of articles including the term environment, to the total number of articles included in the database for each year. 


\section{RESULTS}

TABLE 2 presents descriptive statistics for the total sample of firms (panel A) and the sub-sample of firms disclosing environmental information (panel B). A comparison of the statistics in both panels provides some preliminary evidence on the existence of differences in the environmental disclosure policies of Spanish companies.

TABLE 2

Descriptive Statistics ${ }^{a}$

PANEL A: Full Sample (1991-1995)

\begin{tabular}{|llllllll|}
\hline $\mathrm{N}=560$ & Mean & Median & St. Dev. & Max & Min & Skewness & Kurtosis \\
$\mathrm{P}_{\text {it }}$ & 2601.84 & 1687.50 & 2670.70 & 21460 & 37.22 & 2.212 & 10.573 \\
$\mathrm{~B}_{\text {it }}$ & 2560.12 & 1867.08 & 2802.28 & 33254.3 & -753.72 & 4.251 & 36.489 \\
$\mathrm{X}_{\mathrm{it}}$ & 183.65 & 108.03 & 532.02 & 5444.02 & -1535 & 4.062 & 36.582 \\
$\mathrm{~S}_{\mathrm{it}}$ & 23.801 & 23.813 & 1.758 & 28.246 & 19.472 & 0.046 & 2.882 \\
$\beta_{\mathrm{it}}$ & 1.324 & 1.269 & 0.903 & 3.947 & -0.369 & 0.385 & 2.442 \\
$\mathrm{ROE}$ & -0.030 & 0.066 & 0.949 & 3.349 & -18.011 & -15.172 & 280.66 \\
$\mathrm{ROA}$ & 0.052 & 0.066 & 0.098 & 0.842 & -0.587 & -1.008 & 20.475 \\
$\mathrm{~L}$ & 0.824 & 0.541 & 3.297 & 28.571 & -48.309 & -4.519 & 126.40 \\
$\mathrm{MRG}$ & 0.107 & 0.086 & 0.383 & 4.884 & -4.944 & -0.737 & 117.27 \\
ATR & 0.837 & 0.751 & 0.574 & 3.243 & 0.022 & 1.386 & 5.187 \\
LINE & 5.45 & 0.00 & 16.00 & 145.00 & 0.00 & 4.508 & 24.756 \\
SPACE & 2.35 & 0.00 & 6.10 & 40.71 & 0.00 & 3.616 & 14.271 \\
Media Articles & 0.61 & 0.00 & 1.57 & 11.00 & 0.00 & 4.006 & 18.215 \\
Negative Media Articles & 0.13 & 0.00 & 0.48 & 4.00 & 0.00 & 4.515 & 23.025 \\
\hline
\end{tabular}

PANEL B: Firms Reporting Environmental Information Between 1991 and 1995

\begin{tabular}{|llllllll|}
\hline $\mathrm{N}=142$ & Mean & Median & St. Dev. & Max & Min & Skewness & Kurtosis \\
$\mathrm{P}_{\text {it }}$ & 2915.15 & 2015 & 3018.19 & 21460 & 73 & 2.73 & 12.41 \\
$\mathrm{~B}_{\mathrm{it}}$ & 2279.58 & 2027.08 & 1567.98 & 6592.56 & -163.53 & 0.913 & 0.400 \\
$\mathrm{X}_{\mathrm{it}}$ & 153.63 & 127.78 & 291.79 & 1030.21 & -735.71 & -0.172 & 1.260 \\
$\mathrm{~S}_{\mathrm{it}}$ & 24.612 & 24.784 & 1.833 & 28.245 & 20.088 & -0.257 & -0.134 \\
$\beta_{\mathrm{it}}$ & 1.624 & 1.592 & 0.776 & 3.557 & -0.011 & 0.039 & 0.067 \\
$\mathrm{ROE}$ & -0.017 & 0.062 & 0.554 & 0.598 & -5.451 & -8.580 & 83.881 \\
$\mathrm{ROA}$ & 0.053 & 0.074 & 0.080 & 0.154 & -0.274 & -2.152 & 8.086 \\
$\mathrm{~L}$ & 0.855 & 0.655 & 1.301 & 9.681 & -2.643 & 3.505 & 24.801 \\
$\mathrm{MRG}$ & 0.106 & 0.108 & 0.174 & 0.508 & -0.907 & -2.120 & 12.627 \\
ATR & 0.709 & 0.615 & 0.427 & 2.659 & 0.134 & 1.706 & 6.775 \\
LINE & 21.492 & 10 & 25.844 & 145 & 2 & 2.182 & 5.491 \\
SPACE & 9.28 & 5.49 & 9.102 & 40.714 & 0.783 & 1.649 & 2.058 \\
Media Articles & 1.58 & 0.00 & 2.63 & 11 & 0 & 2.083 & 3.590 \\
Negative Media Articles & 0.36 & 0.00 & 0.78 & 4 & 0 & 2.493 & 6.091 \\
\hline
\end{tabular}

a $P_{i t}$ is the end of the year stock price, $B_{i t}$ is the end of the year book value of equity, $X_{i t}$ is earnings before extraordinary items and discontinuing operations, $S_{i t}$ is the firm's size measured as the logarithm of the total year end market capitalization value, $\beta_{i t}$ is the market model beta estimated on the basis of 36 monthly returns, ROE is the return on common shareholders' equity, ROA is return on 
assets, $\mathrm{L}$ is the debt to equity ratio, MRG is earnings to sales ratio, ATR is the assets turnover: sales divided by total assets, LINE is the total number of lines of environmental information, SPACE is the number of lines of environmental information relative (per thousand) to the total information disclosed in the annual report.

The median size of firms reporting environmental information is greater than the median size of the firms in the total sample. The difference in the average firm size between the two groups is significant at the $99 \%$ level. Although no causality relationship may be inferred from this result, it appears to be consistent with the view that environmental information is disclosed as a result of external pressure and that larger firms are likely to be affected by a greater pressure than smaller firms.

Consistent with the findings of Trotman and Bradley (1981), who found that Australian companies reporting on social issues showed a higher beta, we found that the average market model beta was higher for firms reporting environmental information (see TABLE 2). This suggests that if there is a specific risk factor in firms disclosing environmental information (that could be related to the existence of probable future environmental costs and liabilities) beta either captures it or, at least, is directly associated with it. The mean (median) market model beta of the firms disclosing environmental information was 1.624 (1.592) and the average (median) beta of companies not reporting on environmental issues 1.230 (1.094). The difference in means was significant at the $99 \%$ level. $^{5}$

The Earnings-to-Price and Book-to-Market ratios ${ }^{6}$ were lower for the sub-sample of firms reporting environmental information. However, no significant differences were found in ROE, ROA or gross margin. The mean and median asset turnover (sales-to-total assets) ratio was significantly lower for the firms disclosing environmental information and their average and median leverage (debt-to-equity) were higher than in the case of firms not disclosing information on environmental issues. This may be due to the fact that most firms in this subsample are capital intensive and operate with a high leverage.

\footnotetext{
${ }^{5}$ As in all empirical studies in capital markets based research in accounting, the significance of the statistics used in our analysis does not imply the existence of causality. The fact that the average size or the mean beta are significantly greater for firms disclosing environmental information does not imply that size or risk are the factors driving the voluntary disclosure of information on environmental issues.
} 
An examination of the print media coverage of the environmental implications of Spanish corporations (TABLE 3) reveals that the mean media coverage, total and negative, is larger for firms disclosing environmental information than for the full sample. This finding is consistent with the view (although it does not imply) that firms make environmental disclosures as a response to the societal environmental demands, mirrored in the media coverage of their environmental implications.

\section{The trend in environmental disclosure in Spain}

TABLE 3 provides a summary of the evolution of the environmental disclosure measures between 1991 and 1995. 25.4\% of the companies analyzed were found to disclose some information related to environmental issues, with a significant increase from 1991 to 1993, and a decrease thereafter. Moneva and Llena (1996) found that $70 \%$ of Spanish companies disclosed some environmental information in 1992. However, their sample was limited to the industries in which we found a greater amount of companies disclosing environmental information.

Both, the absolute and the relative number of lines of environmental information in the annual report were significantly higher (at the 95\% level) in all years (except in 1991) for the firms reporting environmental information in all years than for those reporting less frequently.

The results presented in TABLE 3 also indicate that the amount of environmental disclosure in Spanish annual reports varies significantly across years.

\section{TABLE 3}

Average amount of environmental information in the annual reports, by year.

\begin{tabular}{|lllllll|}
\hline & 1991 & 1992 & 1993 & 1994 & 1995 & TOTAL \\
Number of firms disclosing & 23 & 28 & 33 & 31 & 27 & 142 \\
$\begin{array}{l}\text { environmental information } \\
\text { Percentage of the sample }\end{array}$ & $20,5 \%$ & $25,0 \%$ & $29,5 \%$ & $27,7 \%$ & $24,1 \%$ & $25,4 \%$ \\
LINE & 29,65 & 17,82 & 21,91 & 22,10 & 17,15 & 21,49 \\
\hline
\end{tabular}

\footnotetext{
${ }^{6}$ This statement is based on the ratio of average earnings to both, average book value of equity and average price in panels A and B of table 2. The statement also holds for the average and median Earnings-to-Price and Bookto-Market. Descriptive statistics for these ratios are not reported but are available from the authors upon request. 
ENVIRONMENTAL DISCLOSURE IN SPAIN:

CORPORATE CHARACTERISTICS AND MEDIA

EXPOSURE

\begin{tabular}{|lllllll|}
\hline SPACE & 10,82 & 8,73 & 9,37 & 9,12 & 8,60 & 9,28 \\
LINEFREQ & 45,92 & 30,17 & 40,92 & 38,58 & 24,17 & \\
SPACEFREQ & 14,07 & 12,62 & 13,71 & 13,70 & 11,74 & \\
\hline
\end{tabular}

LINE is the total number of lines of environmental information.

SPACE is the number of lines of environmental information relative (per thousand) to the total information disclosed in the annual report.

LINEFREQ is the LINE variable computed only on the basis of the sample of companies that mentioned the environment regularly from 1991 to 1995 in their annual reports.

SPACEFREQ is the SPACE variable computed only on the basis of the sample of companies that mentioned the environment regularly from 1991 to 1995 in their annual reports.

Size

In order to test whether larger firms disclose a greater amount of environmental information we retained all firms disclosing some environmental information and regressed our two measures of the absolute (LINE) and relative (SPACE) amount of environmental information in the annual report on a measure of firm size and the market model beta. Results in panel A of TABLE 4 indicate that firm size has only a marginal explanatory power for the total number of lines of environmental information included in the annual report. However, this result was only found in the pooled regression, and thus might be due to the existence of cross-sectional correlation in the residuals. To control for the size of the annual report, we regressed our SPACE variable on firm size and beta. Results in panel B of TABLE 4 indicate that firm size does not explain the cross-sectional variations in the space devoted to environmental information in the annual report. Overall, although there appears to be a positive relationship between the size of companies and the decision to disclose environmental information, the association was not found to be statistically significant. Consequently, although the average size of companies reporting environmental information is significantly greater than the average size of firms not disclosing information on environmental issues (TABLE 2), we cannot conclude that differences in size across firms explain the differences in the amount of environmental information included in their annual reports.

TABLE $4^{\text {a b }}$

Explanatory power of firm size and market model beta for the total and relative amount of environmental information disclosed in the annual reports

Panel A: Total amount of environmental information. 


\section{EXPOSURE}

Model: $\mathrm{LINE}_{\mathrm{it}}=\phi_{0}+\phi_{1} \mathrm{~S}_{\mathrm{it}}+\phi_{2} \beta_{\mathrm{it}}+\varepsilon_{\mathrm{it}}$

\begin{tabular}{|c|c|c|c|c|c|}
\hline & $\phi_{0}$ & $\phi_{1}$ & $\phi_{2}$ & $\mathrm{R}^{2}$ & $\begin{array}{l}\text { F } \\
\text { (Prob) }\end{array}$ \\
\hline Pooled Sample & $\begin{array}{l}-55.549 \\
(-1.65)\end{array}$ & $\begin{array}{l}2.884^{* *} \\
(2.12)\end{array}$ & $\begin{array}{l}4.962 \\
(1.55)\end{array}$ & 0.045 & $\begin{array}{l}3.611 \\
(0.03)\end{array}$ \\
\hline 1991 & $\begin{array}{l}-196.57 \\
(-1.13)\end{array}$ & $\begin{array}{l}8.363 \\
(1.12)\end{array}$ & $\begin{array}{l}11.611 \\
(1.48)\end{array}$ & 0.001 & $\begin{array}{l}0.933 \\
(0.41)\end{array}$ \\
\hline 1992 & $\begin{array}{c}-36.649 \\
(-0.61)\end{array}$ & $\begin{array}{l}2.257 \\
(0.92)\end{array}$ & $\begin{array}{l}2.156 \\
(0.40)\end{array}$ & 0.001 & $\begin{array}{l}0.501 \\
(0.61)\end{array}$ \\
\hline 1993 & $\begin{array}{l}-10.227 \\
(-0.12)\end{array}$ & $\begin{array}{l}0.878 \\
(0.24)\end{array}$ & $\begin{array}{l}8.567 \\
(0.92)\end{array}$ & 0.001 & $\begin{array}{l}0.536 \\
(0.59)\end{array}$ \\
\hline 1994 & $\begin{array}{l}-81.021 \\
(-1.13)\end{array}$ & $\begin{array}{l}4.103 \\
(1.39)\end{array}$ & $\begin{array}{l}2.171 \\
(0.29)\end{array}$ & 0.011 & $\begin{array}{l}1.143 \\
(0.33)\end{array}$ \\
\hline 1995 & $\begin{array}{l}-50.265 \\
(-1.02)\end{array}$ & $\begin{array}{l}2.585 \\
(1.29)\end{array}$ & $\begin{array}{l}1.985 \\
(0.38)\end{array}$ & 0.005 & $\begin{array}{l}1.060 \\
(0.36)\end{array}$ \\
\hline
\end{tabular}

Panel B: Total amount of environmental information.

Model: $\mathrm{SPACE}_{\mathrm{it}}=\phi_{0}+\phi_{1} \mathrm{~S}_{\mathrm{it}}+\phi_{2} \beta_{\mathrm{it}}+\varepsilon_{\mathrm{it}}$

\begin{tabular}{|c|c|c|c|c|c|}
\hline & $\phi_{0}$ & $\phi_{1}$ & $\phi_{2}$ & $\mathrm{R}^{2}$ & $\begin{array}{l}\text { F } \\
\text { (Prob) }\end{array}$ \\
\hline \multirow[t]{2}{*}{ Pooled Sample } & -0.707 & -0.328 & 0.449 & 0.000 & 0.825 \\
\hline & $(-0.05)$ & $(-0.56)$ & $(0.87)$ & & (0.44) \\
\hline \multirow[t]{2}{*}{1991} & -47.401 & 1.934 & 2.222 & 0.000 & 0.861 \\
\hline & $(-1.00)$ & (1.09) & $(1.21)$ & & (0.44) \\
\hline \multirow[t]{2}{*}{1992} & 16.764 & -0.633 & -0.220 & $0 . .000$ & 0.228 \\
\hline & $(0.48)$ & $(-0.66)$ & $(-0.15)$ & & (0.79) \\
\hline \multirow[t]{2}{*}{1993} & 13.494 & -1.117 & -0.074 & 0.000 & 0.140 \\
\hline & $(0.41)$ & $(-0.48)$ & $(-0.05)$ & & $(0.87)$ \\
\hline \multirow[t]{2}{*}{1994} & -4.750 & -2.712 & 0.724 & 0.024 & 1.312 \\
\hline & $(-0.19)$ & $(-1.37)$ & $(0.72)$ & & (0.28) \\
\hline \multirow[t]{2}{*}{1995} & -2.926 & -2.680 & 0.543 & 0.000 & 1.188 \\
\hline & $(-0.131)$ & $(-1.12)$ & $(0.63)$ & & $(0.32)$ \\
\hline
\end{tabular}

${ }^{\text {a }}$ LINE is the total number of lines of environmental information.

SPACE is the number of lines of environmental information relative (per thousand)

to the total information disclosed in the annual report.

${ }^{\mathrm{b}}$ White heteroscedasticity consistent $\mathrm{t}$-statistics in parentheses.

*** Significant at the $99 \%$ level. ${ }^{* *}$ Significant at the $95 \%$ level.

Risk

Our second conjecture is that the amount of environmental disclosure is some function of firm's perceived level of risk. In order to test for an association between these two variables 
we regressed the two measures of disclosure on firm size and the market model beta. Our results (TABLE 4) reveal that the differences in the level of risk as measured by the beta coefficient do not explain the cross-sectional differences in the relative and absolute amount of environmental information in the annual reports of Spanish listed companies. The lack of explanatory power of market betas found in our analysis is consistent with the results reported by Trotman and Bradley (1981) for Australia.

\section{Corporate characteristics and environmental disclosure}

In order to determine whether there are significant differences in the corporate characteristics most commonly analyzed in the accounting literature between Spanish listed firms disclosing information on environmental issues and those not reporting environmental information, we regressed different variables representing corporate characteristics (return on assets, return on equity, stock returns, size, risk, assets turnover and dividend per share) on a dummy variable taking on the value 1 for firms reporting on environmental issues and 0 otherwise. In so doing, we tested the statistical significance of the difference in means across the two groups of companies. Results not reported here indicate that significant differences only existed in size, market model beta, assets turnover and dividend per share. ${ }^{7}$ Specifically, firms reporting on environmental issues appeared to be (on average) significantly larger in size, have higher betas, lower assets turnover, higher leverage and, lower dividends per share. Therefore, it appears that there is no consistent relationship between environmental disclosures and profitability or market performance. We found no significant relationship between the firms' stock returns and the extent of environmental disclosure.

\section{Environmental sensitivity}

The sample included 112 industrial firms, 28 of which operated in the more sensitive industries, i.e. electric utilities and gas, oil and mining, chemical and pulp and paper. 17 (60\%) of companies in more sensitive industries made environmental disclosures in any year in the period 1991-1995, whereas 32 (38\%) of companies in other industries did make any environmental disclosure. We analysed 140 annual reports for companies in more sensitive industries, 71 of which $(51 \%)$ included some environmental information. From the remaining 420 annual reports, 71 (17\%) included environmental information. These results clearly

\footnotetext{
${ }^{7}$ These results are available from the authors upon request. 
indicate that environmental disclosures are more often found in the annual reports of firms operating in more sensitive industries.

We regressed our two measures of environmental disclosure on $\mathrm{D}$, a dummy variable taking on the value one for firms in the more sensitive industries. Results in TABLE 5 suggest that there is a positive and consistent relationship between the amount of environmental information disclosed and the environmental sensitivity of the company. Panel A indicates that, in all years, the total number of lines of environmental information in the annual reports is consistently related with the sensitivity of the industry. The average total number of lines is significantly higher for firms operating in environmentally sensitive industries. Similar results, excepted for 1991 and 1992, were found when the relative number of lines of environmental information was used as the dependent variable (see panel B).

\section{TABLE $5^{\mathrm{a} b}$}

Explanatory power of environmental sensitivity for the total and relative amount of environmental information disclosed in the annual reports

Panel A: Total amount of environmental information. Model: LINE $_{i t}=\psi_{1}+\psi_{2} D_{i t}+\varepsilon_{i t}$

$\begin{array}{lllll} & \psi_{1} & \psi_{2} & \mathrm{R}^{2} & \begin{array}{l}\mathrm{F} \\ \text { (Prob) }\end{array} \\ \text { Pooled Sample } & 1.152^{* * *} & 18.883^{* * *} & 0.236 & 145.21 \\ & (5.07) & (6.95) & & (0.00) \\ 1991 & 1.296 & 18.975^{* * *} & 0.173 & 18.863 \\ & (1.49) & (2.68) & & (0.00) \\ 1992 & 0.794^{*} & 15.727^{* * *} & 0.277 & 37.465 \\ & (1.83) & (3.58) & & (0.00) \\ 1993 & 1.391^{* * *} & 23.216^{* * *} & 0.225 & 28.950 \\ & (3.29) & (3.04) & & (0.00) \\ 1994 & 1.297^{* * *} & 21.137^{* * *} & 0.285 & 39.407 \\ & (3.09) & (3.58) & & (0.00) \\ 1995 & 0.985^{* * *} & 14.814^{* * *} & 0.290 & 37.383 \\ & (2.83) & (3.38) & & (0.00)\end{array}$

Panel B: Relative amount of environmental information. Model: $\mathrm{SPACE}_{\mathrm{it}}=\varphi_{0}+\varphi_{1} \mathrm{D}_{\mathrm{it}}+\varepsilon_{\mathrm{it}}$

$\begin{array}{lllll} & \varphi_{0} & \varphi_{1} & \mathrm{R}^{2} & \mathrm{~F} \\ & & & & (\text { Prob) } \\ \text { Pooled Sample } & 5.061^{* * *} & 7.047^{* * *} & 0.158 & 21.88 \\ & (9.22) & (5.71) & & (0.00) \\ 1991 & 6.693 & 5.859 & 0.003 & 1.054\end{array}$


EXPOSURE

$\begin{array}{lllll} & (1.35) & (1.02) & & (0.32) \\ 1992 & 4.479 & 7.350 & 0.049 & 1.984 \\ & (0.99) & (1.41) & & (0.17) \\ 1993 & 5.134^{* * *} & 10.083^{* * *} & 0.216 & 8.195 \\ & (4.51) & (2.94) & & (0.00) \\ 1994 & 4.791^{* * *} & 9.161^{* * *} & 0.241 & 8.974 \\ & (5.96) & (3.42) & & (0.00) \\ & 4.885^{* * *} & 4.559^{* *} & 0.104 & 3.577 \\ & (5.00) & (2.24) & & (0.07)\end{array}$

a $D_{i t}$ is a dummy variable taking on the value one for firms reporting environmental information that operate in the oil and mining, electricity and gas, chemical and pulp and paper industries and, zero otherwise. See footnote to TABLE 2 for variable definitions.

${ }^{\mathrm{b}}$ White heteroscedasticity consistent $\mathrm{t}$-statistics in parentheses.

*** Significant at the $99 \%$ level. ${ }^{* *}$ Significant at the $95 \%$ level. ${ }^{*}$ Significant at the $90 \%$ level.

\section{Media exposure}

According to the discussion presented above environmental disclosure should increase with media coverage of the environmental impact of firm. FIGURE 1 presents the time series behavior of three variables: the amount of environmental information disclosed by firms reporting on environmental issues in all years (LINEFREQ), the number of firms making environmental disclosures only sporadically (SPO), and the Total Environmental Articles published in Spain, which could be interpreted as a proxy for the social concern for environmental issues of the Spanish society.

FIGURE 1

Societal expectations and environmental disclosure.

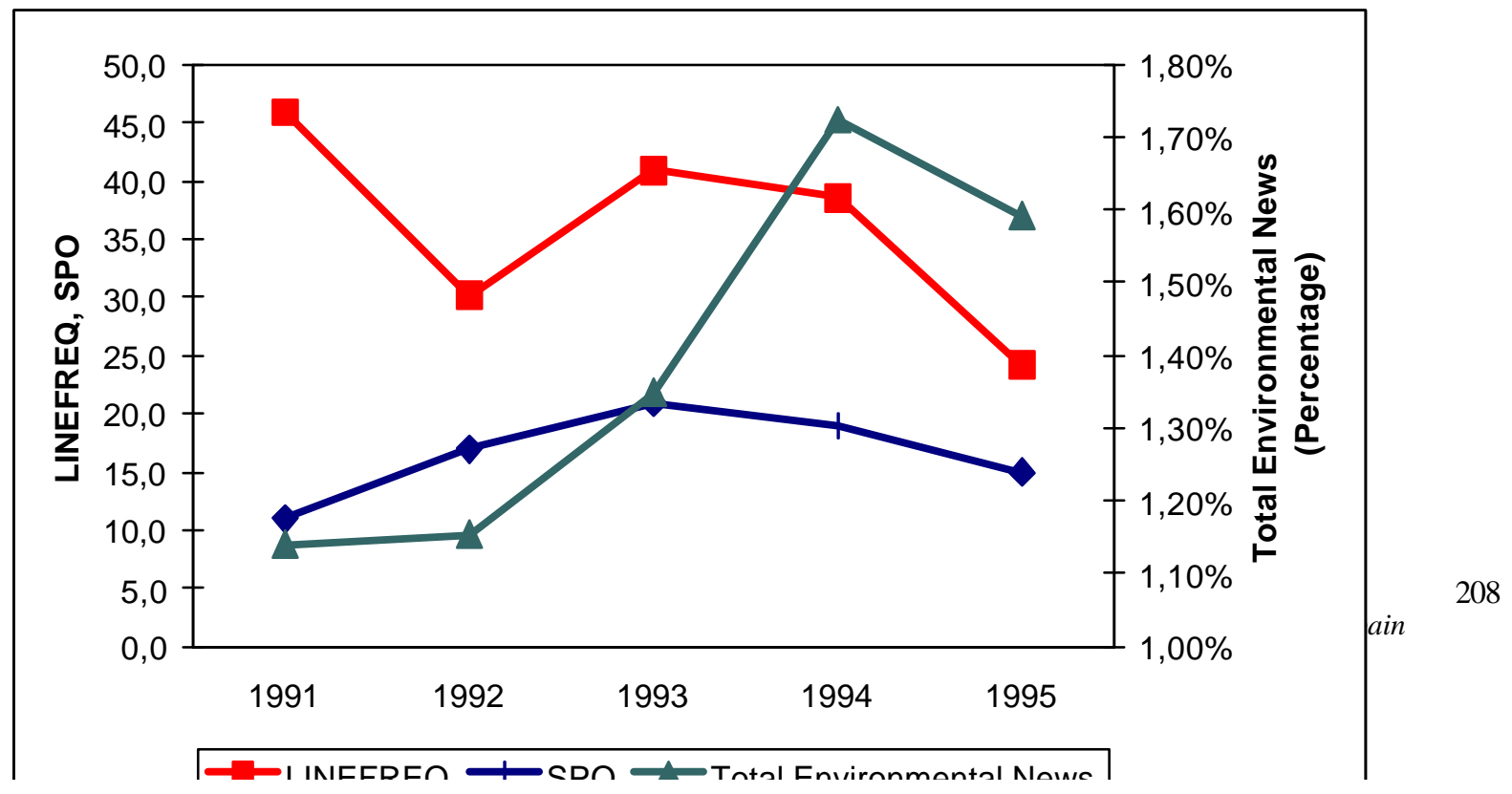


Total Environmental Articles is the percentage of articles including at least one reference to environmental issues. LINEFREQ is the average number of lines in all the reports analyzed that contained environmental information regularly from 1991 to 1995 . SPO is the number of companies disclosing environmental information during the period considered, but not in all the years.

The growing pattern shown by the total number of articles dealing with the environment indicates that there is a growing concern for environmental issues in Spain. The growth rate seems to be particularly high between 1992 and 1994. In our view, this could be the result of the growing attention paid by the press to environmental issues following the Rio Summit in 1992. The amount of lines of environmental disclosure by the most active companies, as well as the number of firms that only disclosed occasionally showed a similar pattern during this period. This would be consistent with the idea (although does not necessarily imply) that the disclosure of environmental information by Spanish firms is related to the degree of social concern for environmental issues. A possible explanation for the decrease in the amount of environmental disclosure in corporate financial reports is that in the early 1990s a process of stringent environmental regulation started as a result of the general concern for environmental issues. Companies that were able to anticipate the changes would have increased the amount of environmental information in their annual reports in order to enhance their image in the eyes of their stakeholders. By 1995 firms were feeling less pressure and hence the lower amount of environmental information disclosed in their reports.

In order to test for a relationship between media coverage and the disclosure of environmental information in the annual reports of Spanish listed firms, we computed the Spearman rank-order correlation coefficients for a set of four variables: our measures of the level of environmental disclosure (LINE and SPACE) and two measures of media coverage of environmental issues. The results in TABLE 6 show that, for each year and for the pooled sample, there is a positive and statistically significant (at the $99 \%$ level) association between media coverage and environmental disclosures. However, we found low correlations ranging from a minimum 0.136 to a maximum 0.449 . 
TABLE 6

Spearman rank-order correlation coefficients between different measures of environmental disclosure and media articles relating the firm with environmental issues ${ }^{\mathrm{a}}$

\begin{tabular}{|c|c|c|c|c|}
\hline \multirow{3}{*}{ Pooled Sample } & & $\mathrm{N}$ & Media articles & $\begin{array}{l}\text { Negative media } \\
\text { articles }\end{array}$ \\
\hline & LINE & 560 & $0.357^{* * *}$ & $0.320^{* * *}$ \\
\hline & SPACE & 560 & $0.344^{* * *}$ & $0.307^{* * *}$ \\
\hline \multirow{2}{*}{1991} & LINE & 112 & $0.426^{* * *}$ & $0.449^{* * *}$ \\
\hline & SPACE & 112 & $0.410^{* * *}$ & $0.446^{* * *}$ \\
\hline \multirow{2}{*}{1992} & LINE & 112 & $0.302^{* * *}$ & $0.307^{* * * *}$ \\
\hline & SPACE & 112 & $0.283^{* * *}$ & $0.283^{* * *}$ \\
\hline \multirow{2}{*}{1993} & LINE & 112 & $0.415^{* * *}$ & $0.322^{* * *}$ \\
\hline & SPACE & 112 & $0.403^{* * *}$ & $0.321^{* * *}$ \\
\hline \multirow{2}{*}{1994} & LINE & 112 & $0.364^{* * *}$ & $0.159^{* * *}$ \\
\hline & SPACE & 112 & $0.348^{* * *}$ & $0.136^{* * *}$ \\
\hline \multirow{2}{*}{1995} & LINE & 112 & $0.313^{* * *}$ & $0.395^{* * *}$ \\
\hline & SPACE & 112 & $0.316^{* * *}$ & $0.414^{* * *}$ \\
\hline
\end{tabular}

a LINE is the total number of lines of environmental information.

SPACE is the number of lines of environmental information relative (per thousand) to the total information disclosed in the annual report.

*** Significant at the $99 \%$ level.

\section{CONCLUDING REMARKS}

This paper analyzes environmental reporting practices in Spain on the basis of a crosssectional sample of firms listed on the Madrid Stock Exchange between 1991 and 1995. Our results suggest that environmental reporting increased significantly in Spain in the early 1990s, probably as a result of an increase in social concerns for environmental issues. 
However, Spanish companies still appear to disclose a low amount of environmental information, particularly if compared to firms in other developed countries.

Our analysis revealed that firms disclosing environmental information tend to be larger, have a higher systematic risk and operate in more sensitive industries. Their environmental implications seem to receive greater attention from the print media. These results are consistent with the empirical evidence published in the literature to date. Firms reporting environmental information also showed lower dividends per share, lower levels of assets turnover and higher leverage, consistent with the idea that they are large and capital intensive. Finally, we found no consistent association between profitability and the decision to disclose environmental information in the annual reports of Spanish listed firms.

As for the amount of information disclosed by Spanish companies in their annual reports, only the environmental sensitiveness of the industry in which the firm operates and the media coverage of corporate environmental activities seem to have some explanatory power, whereas size and risk do not seem to be able to explain the cross-sectional differences in the extent of environmental disclosure in Spain. 


\section{REFERENCES}

AlnaJjAR, F.K. (2000), 'Determinants of Social Responsibility Disclosure of U.S. Fortune 500 Firms: An Application of Content Analysis", Advances in Environmental Accounting and Management, Vol. 1, pp.163-200.

ARChEL, P. AND F. LIZARRAGA (2001), "Algunos Determinantes de la Información Medioambiental Divulgada por las Empresas Españolas Cotizadas", Revista de Contabilidad, Vol. 4, No. 7, pp. 129-153.

Bebbington, J., Gray, R., Thomson, I. And D. Walters (1994), “Accountants' Attitudes and Environmental-sensitive Accounting" Accounting and Business Research, Vol. 24, No. 94, pp.109-120.

BEWLEY, K. AND Y. LI (1998), "Disclosure of Environmental Information by Canadian Manufacturing Companies: A Voluntary Disclosure Perspective", Advances in Environmental Accounting and Management, Vol. 1, pp.201-226.

BRown, N. AND C. DEEgAN (1998), "The Public Disclosure of Environmental Performance Information - A Dual Test of Media Agenda Setting Theory and LT", Accounting and Business Research, Vol. 29, No. 1, pp. 21-41.

Bushman, R.M. AND A.J. SMITH (2001), "Financial Accounting Information and Corporate Governance". Journal of Accounting and Economics, Vol. 32, pp. 237-333.

CARMONA, S. AND F. CARRASCo (1988), "Información de Contenido Social y Estados Contables: Una Aproximación Empírica y Algunas Consideraciones Teóricas" Actualidad Financiera, pp. 2175-2192.

CARRASCO F AND C. LARRINAGA (1995), "Organizaciones, contabilidad y el entorno natural. Una perspectiva andaluza" Revista Española de Financiación y Contabilidad, Vol. 24, No. 83, pp.393-416.

CICA (1994), Environmental Reporting in Canada: A Survey of 1993 Reports. Canadian Institute of Chartered Accountants.

DEEGAN, C. (2002), "The Legitimating Effect of Social and Environmental Disclosures - A Theoretical Foundation" Accounting, Auditing and Accountability Journal, Vol. 15, No. 3, pp. 281-311.

DEEGAN, C. AND B. GORDON (1996), "A Study of the Environmental Disclosure Practices of Australian Corporations" Accounting and Business Research, Vol. 26, No. 3, pp. 187-199.

DeEgAN, C. AND M. RANKIn (1996), "Do Australian Companies Report Environmental News Objectively? An Analysis of Environmental Disclosures by Firms Prosecuted successfully by the Environmental Protection Authority" Accounting, Auditing and Accountability Journal, Vol. 9, No. 2, pp. 50-67.

DEEGAN, C. AND M. RANKIN (1997), "The Materiality of Environmental Information to Users of Annual Reports" Accounting, Auditing and Accountability Journal, Vol. 10, No. 4, pp. 562-583.

DYE, R.A. (2001), "An Evaluation of 'Essays on Disclosure' and the Disclosure Literature". Journal of Accounting and Economics, Vol. 32, pp. 181-235.

GRAY R., R. KOUHY AND S. LAVERS (1995A), "Corporate Social Reporting: A Review of the Literature and a Longitudinal Study of UK Disclosure" Accounting, Auditing and Accountability Journal Vol. 8, No. 2, pp. 47-77. 
GRAY R., R. KOUHY AND S. LAVERS (1995B), "Constructing a Research Database of Social and Environmental Reporting by UK Companies" Accounting, Auditing and Accountability Journal Vol. 8, No. 2, pp. 78-101.

GraY, R., M. JAVAD, D.M. POWER AND C.D. SinclaIR (2001), "Social and Environmental Disclosure and Corporate Characteristics: A Research Note and Extension", Journal of Business Finance and Accounting, Vol. 28, No. 3-4, pp. 327-356.

GuTHRIE, J. AND L. PARKER (1989), "Corporate Social Reporting: A Rebuttal of LT" Accounting and Business Research. Vol. 19, No. 76, pp. 343-352.

HaCKstON, D. AND M.J. MiLNE (1996), "Some Determinants of Social and Environmental Disclosures in New Zealand", Accounting, Auditing and Accountability Journal Vol. 9, No. 1, pp. 77-108.

VERRECHIA, R.E. (2001), "Essays on Disclosure". Journal of Accounting and Economics, Vol. 32, pp. 97-180.

Hughes S.B., A. ANDERSON AND S. GOLDEN (2001), "Corporate Environmental Disclosures: Are They Useful in Determining Environmental Performance?" Journal of Accounting and Public Policy, Vol. 20, pp. 217-240.

INGRAM, R.W. AND K.B. FRAZIER (1980), "Environmental Performance and Corporate Disclosures", Journal of Accounting Research, Vol. 18, No. 2, Autumn, pp. 614-622.

KPMG (2002), KPMG International Survey of Corporate Sustainability Reporting 2002. Amsterdam.

Larrinaga, C., Llena, F., Moneva, J.M., CArrasco, F. And CorreA, C. (2002) Accountability and accounting regulation: The case of the Spanish environmental disclosure standard, European Accounting Review, Vol. 11, No.4, pp. 723-740.

LI, Y, G.D. RICHARDSON AND D.B. THORNTON (1997), "Corporate Disclosure of Environmental Liability Information: Theory and Evidence". Contemporary Accounting Research, Vol 14, n.3.

MiLNE, M.J. AND R.W. ADLER (1999), "Exploring the Reliability of Social and Environmental Disclosures Content Analysis", Accounting, Auditing and Accountability Journal Vol. 12, No. 2, pp. 237-256.

MONEVA, J.M. AND F. LlENA (1996), “Análisis de la Información sobre Responsabilidad Social en las Empresas Industriales que Cotizan en Bolsa" Revista Española de Financiación y Contabilidad, Vol. 25, No. 87, pp.361-401.

MonEVA, J.M. AND F. LLENA (2000), "Environmental Disclosures in Annual Reports of Large Companies in Spain” European Accounting Review, Vol. 9, No. 1, pp. 7-29.

NÄSI, J.; S. NÄSI, N. PHILLIPS AND S. ZYGLIDOPOULOS (1997) "The evolution of corporate social responsiveness. An exploratory study of Finnish and Canadian Forestry Companies" Business and Society, vol. 26, No. 3, September, pp. 296-321.

PATTEN, D. (1992), "Intra-Industry Environmental Disclosure in Response to the Alaskan Oil Spill: A Note on LT" Accounting, Organizations and Society, Vol. 17, No. 5, pp. 471-475.

Unerman, J. (2000), "Reflections on Quantification in Corporate Social Reporting Content Analysis", Accounting, Auditing and Accountability Journal Vol. 13, No. 5, pp. 667-680.

WALDEN, W.D. AND B.N. SchWARTZ (1997), "Environmental Disclosures and Public Policy Pressure". Journal of Accounting and Public Policy, Vol. 16, pp. 125-154.

HARTE, G. AND D. OWEN (1992), "Current Trends in the Reporting of Green Issues in the Annual Reports of United Kingdom Companies", in Green Reporting: Accountancy and the Challenge of the Nineties. D. Owen (ed.) Chapman and Hall. New York, pp. 166-200. 
ROCKNESS J.W. (1985): "An Assessment of the Relationship Between US Corporate Environmental Performance and Disclosure". Journal of Business Finance \& Accounting, Vol. No. pp. 339-354.

WisEMAN J. (1982), "An Evaluation of Environmental Disclosure Made in Corporate Annual Reports", Accounting, Organizations and Society, Vol. 7, No. 1, pp. 53-63.

COWEN S.S., FERRERI L.B. Y PARKER L.D. (1987): "The Impact of Corporate Characteristics on Social Responsibility Disclosure: A Typology and Frequency-Based Analysis". Accounting, Organizations and Society, Vol. 12, No. 2, pp. 111-122.

PATTEN D.M. (1991): "Exposure, Legitimacy, and Social Disclosure". Journal of Accounting and Public Policy, Vol. 10, No. 4, pp. 297-308.

RoBERTS R.W. (1992): "Determinants of Corporate Social Responsibility Disclosures: An Application of Stakeholder Theory". Accounting, Organizations and Society, Vol. 17, No. 6, pp. 595-612.

TROTMAN K.T. Y BRADLEY G.W. (1981): "Associations between Social Responsibility Disclosure and Characteristics of Companies". Accounting, Organizations and Society, Vol. 6, No. 4, pp. 355-362.

UlLmANN A.A. (1985): "Data In Search of a Theory: A Critical Examination of the Relationship Among Social Performance, Social Disclosure". Academy of Management Review, Vol. 10, No. 3, pp. 540-557. 